Sacrificing Families 



\section{Sacrificing Families}

Navigating Laws, Labor, and Love Across Borders

Leisy J. Abrego 
Stanford University Press

Stanford, California

(C) 2014 by the Board of Trustees of the Leland Stanford Junior University.

All rights reserved.

No part of this book may be reproduced or transmitted in any form or by any means, electronic or mechanical, including photocopying and recording, or in any information storage or retrieval system without the prior written permission of Stanford University Press.

Printed in the United States of America on acid-free, archival-quality paper

Library of Congress Cataloging-in-Publication Data

Abrego, Leisy J., author.

Sacrificing families : navigating laws, labor, and love across borders / Leisy J. Abrego. pages $\mathrm{cm}$

Includes bibliographical references and index.

ISBN 978-0-8047-8831-1 (cloth : alk. paper) - ISBN 978-0-8047-9051-2 (pbk. : alk. paper)

1. Salvadorans-Family relationships-United States. 2. Immigrants-Family relationships-United States. 3. Immigrants-Family relationships-El Salvador.

4. Immigrant families-El Salvador. 5. Children of immigrants-El Salvador.

6. El Salvador-Emigration and immigration-Social aspects. 7. United StatesEmigration and immigration-Social aspects. I. Title.

E184.S15A27 2014

$305.868^{\prime} 7284073-\mathrm{dc} 23$

2013036755

ISBN 978-0-8047-9057-4 (electronic)

Typeset by Thompson Type in 10/14 Minion 
Para Margoth y Douglas Abrego por su cariño y sus sacrificios

Para Carlos Colorado porque es bello formar una familia con vos 
